\title{
Pemuliaan Angklung melalui Model Desa Binaan Berbasis Wisata Seni dan Budaya
}

\author{
Juju Masunah \\ Universitas Pendidikan Indonesia (UPI) Bandung \\ Jalan Setiabudi 229 Bandung
}

\begin{abstract}
Angklung has been awarded by UNESCO as one of the intangible world heritages from Indonesia. One of the angklung preservation methods is through community based education. This article describes the result of research and community service activities to explore a model of community empowerment based on art and culture that uses Sundanese angklung instruments and local traditional performing arts to attract tourism in Ciater Village, Subang. This research used a participatory action research method where researchers participate actively along with the community to create a touristic event involving art and culture. The findings of this research present that to empower a community using art and culture as an event for a tourist destination occurs by a collaborative work between local community, intelectuals, and bussiness. The community of Ciater village presented their innovation and creativity with Sundanese angklung music and local traditional performing arts in order to serve seventy tourists (artists) from Southeast Asia and Europe on October 7, 2011 for the first time.
\end{abstract}

Keywords: Sundanese angklung, tourism of culture, Ciater Village.

\section{Pendahuluan}

Salah satu cara pemuliaan angklung adalah melalui pendidikan masyarakat dalam konteks pengembangan desa binaan berbasis wisata seni dan budaya. Angklung adalah alat musik terbuat dari bambu yang memiliki dua sampai tiga tabung tergantung pada rangka dan dimainkan secara digoyang, ditengkep, atau digetarkan. Sejak tahun 2010, angklung telah diakui oleh UNESCO sebagai warisan budaya dunia 'tak benda' dari Indonesia. Di Saung Angklung Udjo dikenal angklung Sunda dan angklung Indonesia (Masunah, 2003). Angklung Sunda adalah angklung yang berkembang di desa-desa yang diadopsi oleh Udjo Ngalagena berdasarkan laras pentatonis, sedangkan angklung Indonesia adalah angklung berlaras diatonis yang dikembangkan oleh Daeng Sutigna dengan mengadopsi sistem Barat. Angklung diatonis inilah yang banyak dipelajari di sekolah-sekolah, sedangkan angklung Sunda, ironisnya tidak dikenal.

Desa binaan adalah upaya pendidikan dan pembinaan masyarakat desa, sesuai dengan potensi, masalah, dan kebutuhannya dengan tujuan untuk meningkatkan inovasi, kreativitas, kemandirian, 
gotong royong, dan kesejahteraannya. Wisata seni dan budaya merupakan sebuah peristiwa wisata dimana seni dan budaya menjadi tujuan perjalanan wisatawan. Seringkali pariwisata hanya berorientasi pada produk dan dampak ekonomi, tanpa memperhatikan sebuah proses perkembangan masyarakat penyangganya. Oleh karena itu, tujuan desa binaan ini adalah untuk meningkatkan kesadaran budaya masyarakat dalam merespon kehadiran wisatawan, serta untuk mengeksplorasi model desa binaan berbasis wisata seni dan budaya dengan memanfaatkan musik angklung Sunda dan seni daerah setempat sebagai daya tarik pariwisata di Ciater, Subang.

Desa Ciater telah menjadi salah satu daerah tujuan wisata di Jawa Barat. Kolam pemandian air panas yang dikembangkan oleh Sari ater telah dijadikan daya tarik andalan pariwisata. Potensi lain adalah pegunungan dan hamparan hijau kebun teh yang merupakan daya tarik tersendiri bagi wisatawan mancanegara. Kehadiran wisatawan ke Ciater telah direspon para invenstor dari luar Ciater dengan menjamurnya perusahaan spa, restoran, pembangunan villa, serta perhotelan yang mungkin lambat laun akan merusak ekosistem dan keindahan alam di Ciater. Hal ini tidak boleh dibiarkan karena alam merupakan penyangga utama kehidupan suatu masyarakat. Sebagian masyarakat di sekitarnya merespon kehadiran wisatawan dengan berjualan makanan sebagai usaha kecil, perbengkelan, tukang parkir, dan pengojeg, menjadi pegawai tetap dan tidak di perusahaan spa serta perhotelan. Sebagian besar pekerja yang ada di pusat-pusat wisata berasal dari luar Subang. Orang luar Subang, baik pengusaha maupun pekerja mempunyai posisi lebih tinggi dibandingkan orang Ciater sendiri. Hal ini berdampak pada masalah sosial yang tidak diharapkan seperti demo pemuda dan kriminalitas. Di sisi lain, kekayaan seni tradisional Ciater belum dapat dioptimalkan sebagai daya tarik pariwisata yang dapat menambah pendapatan masyarakat.

Untuk mengembangkan Desa Binaan ini, penulis meminjam konsep Budaya Pariwisata dan Pariwisata Budaya yang dirumuskan oleh Michel Picard (2006). Picard (2000) berpendapat bahwa budaya pariwisata adalah pola hubungan antara dalam (kami) dan luar (mereka). Kami berkaitan dengan nilai-nilai budaya dari masyarakat yang dikunjungi dan mereka berkaitan dengan nilai ekonomi dari masyarakat pengunjung (wisatawan). Pertemuan antara kami dan mereka akan memotivasi munculnya bentuk pariwisata yang saling menguntungkan kedua belah pihak. Pihak dalam akan meningkat inovasi dan kreativitasnya untuk melihat potensi dirinya. Bersamaan dengan itu masyarakat akan mengubah cara pandang terhadap dirinya dan tumbuh kebanggaan akan potensinya. Bagi wisatawan, mereka akan mendapatkan pengalaman budaya dari budaya masyarakat yang dikunjunginya. Dengan kata lain, konsep pariwisata disini bukanlah merombak suatu masyarakat dari luar, melainkan mengubah masyarakat dari dalam untuk memandang dirinya sendiri.

Untuk menerapkan konsep tersebut di Ciater, penulis menggunakan metode 'partisipatori kaji tindak'. Ada tiga pihak yang berperan dalam pengembangan Desa Binaan berbasis Wisata Seni dan Budaya, yaitu pihak pertama adalah Pemerintah Desa Ciater bersama masyarakatnya, pihak kedua adalah tim dosen UPI, dan pihak ketiga adalah Yayasan Saung Angklung Udjo (S.A.U). Dalam hal ini, tim dosen UPI, 
mahasiswa KKN UPI, dan perwakilan S.A.U menjadi satu tim yang menempatkan diri sebagai masyarakat Ciater yang disebut 'putra daerah' oleh Eep Hidayat, Bupati Subang, 2010. Sebagai masyarakat Ciater, kami ingin membawa perubahan cara pandang dan kesadaran budaya masyarakat dalam merespon kehadiran wisatawan, khususnya dalam pemanfaatan seni tradisional setempat.

Waktu pelaksanaan kegiatan ini dilakukan bersamaan dengan waktu mahasiswa UPI melaksanakan Kuliah Kerja Nyata (KKN), yaitu pada bulan Juli-Agustus. Dalam konteks ini, penulis adalah pembimbing mahasiswa KKN Pos Pemberdayaan Keluarga (POSDAYA) dan sekaligus melaksanakan kegiatan pengabdian kepada masyarakat di Kecamatan Ciater. Tema-tema POSDAYA dapat diselaraskan dengan fokus pemberdayaan masyarakat yang digagas oleh dosen pembimbing, seperti kewirausahaan, pendidikan, dan lingkungan. Dengan demikian, mahasiswa KKN yang menetap di lokasi dapat membantu juga dalam berkomunikasi dan menggerakkan masyarakat desa.

Langkah-langkah yang ditempuh untuk mencapai tujuan di atas adalah: pertama, melakukan studi pendahuluan untuk menganalisis situasi awal di Ciater dengan cara mengkaji potensi, masalah, dan kebutuhan wilayah, serta melakukan program rintisan. Studi pendahuluan dan program rintisan dilaksanakan pada tahun 2010. Program rintisan ini berupa pelatihan guru-guru untuk menggali dan memodifikasi permainan anak-anak menjadi suatu bentuk pertunjukan seni, dan sekaligus melakukan pendekatan struktural untuk memperoleh kesepakatan kerjasama dengan pemerintah setempat. Kedua, merumuskan kerangka konseptual dan meran- cang serta mengimplementasikan kegiatan pendidikan dan pelatihan; ketiga, pelaksanaan kegiatan pelatihan angklung untuk memotivasi masyarakat berkreasi seni dan mengkolaborasikan seni angklung Sunda, permainan anak-anak, dengan seni tradisional setempat. Kegiatan kedua dan ketiga dilaksanakan pada tahun 2011.

Hasil kegiatan ini diharapkan dapat mewujudkan peristiwa wisata seni angklung Sunda, sebagai suatu proses interaksi antara masyarakat Ciater dengan wisatawan. Dampak dari pembinaan ini diharapkan mampu meningkatkan kemandirian masyarakat dalam mengembangkan potensi alam, seni, budaya, dan sumberdaya manusia untuk mencapai kesejahteraan hidup yang lebih baik.

\section{Pelaksanaan dan Pembahasan}

\section{Budaya Pariwisata dan Pariwisata Budaya}

Kerangka konsep pemberdayaan masyarakat yang sesuai dengan potensi, masalah, dan kebutuhan di Ciater adalah teori Pariwisata Budaya dan Budaya Pariwisata yang dikemukakan oleh Michel Picard (2006). Menurut Picard (2006) pariwisata budaya adalah sebuah proses kunjungan wisatawan yang bertujuan mendapatkan pengalaman budaya dari masyarakat yang dikunjunginya, sedangkan budaya pariwisata adalah sebuah proses interaksi masyarakat yang dikunjungi oleh wisatawan, dimana masyarakat tersebut terangsang untuk berinovasi dan berkreativitas serta menggali potensinya untuk melahirkan jasa atau produk yang mempunyai nilai ekonomi. Teori ini diangkat dari studi empirik Picard pada masyarakat Bali. Masyarakat Bali memiliki hubungan antara adat dengan agama (Hindu Bali, yaitu un- 
sur Hindu, Buddha dan elemen animis) sangat kuat yang melahirkan ritual-ritual tertentu. Seni merupakan bagian dari ritual masyarakat Bali, sehingga seniman dan seninya tetap hidup dan berkembang sesuai dengan perkembangan jamannya. Seni, adat, dan agama di Bali menjadi daya tarik tersendiri bagi kehadiran wisatawan. Selanjutnya, interaksi masyarakat Bali dengan wisatawan mempunyai dampak positif bagi perkembangan kesenian yang ditandai oleh munculnya berbagai peristiwa budaya seperti Pekan Kesenian Bali (PKB) yang dilaksanakan setiap tahun, pertunjukan seni yang dikemas khusus untuk ditampilkan di pusat-pusat wisata, seperti barong dan randa, serta tari keris. Bentuk-bentuk sajian seni yang baru ini dapat memberikan pengalaman batin kepada wisatawan, dan dari sisi ekonomi dapat meningkatkan pendapatan masyarakat Bali. Konsep Picard (2006) dapat digambarkan dalam bentuk bagan seperti terlihat pada diagram 1 .

Konsep tersebut menarik untuk dijadikan landasan berpikir dalam pemberdayaan dan pengembangan pariwisata di daerah lain. Namun demikian, ketika akan diterapkan di luar Bali, kita harus mencermati kondisi masyarakat yang ada. Masyarakat Ciater sangat berbeda dengan Bali, jika di Bali nilai-nilai budaya Hindu menyatu dalam kehidupan sehari-hari mereka, nilai-nilai budaya yang berkembang di Ciater lebih bersifat sekuler. Sebagian besar kesenian di Bali sangat berkaitan dengan agama, berbeda dengan kesenian di Ciater yang lebih bersifat keduniawian. Di Ciater, seni merupakan sarana hiburan atau kegiatan sosial saja yang disajikan berdasarkan undangan, baik dari masyarakat (pada acara khitanan dan perkawinan) maupun acara pemerintahan yang sifatnya insidental. Jenis-jenis kesenian tradisi yang masih hidup di Ciater antara lain Jaipongan, Celempungan, Sisingaan, dan Calung. Oleh karena rutinitas pertunjukan di Ciater tidak ada, maka dengan sendirinya seniman sebagai pemelihara kesenian itu kurang berkembang kreativitasnya dan kurang pendapatannya. Di sisi lain, masyarakat sangat memperhatikan tradisi Sunda. Setiap hari kamis, para pimpinan dan tokoh masyarakat yang laki-laki memakai baju tradisi Sunda, kampret berwarna hitam dan memakai iket kepala. Bahasa yang digunakan seharihari dalam berkomunikasi adalah bahasa Sunda. Untuk mengembangkan wisata seni dan budaya di Ciater diperlukan intelektual/seniman yang dapat memotivasi tumbuhnya kesadaran budaya masyarakat untuk meningkatkan inovasi dan kreativitas dalam merespon kehadiran wisatawan. Kami (Tim dosen UPI, S.A.U) sebagai bagian dari masyarakat Ciater menetapkan angklung Sunda sebagai materi pembinaan kesenian untuk dikolaborasikan dengan seni tradisional daerah setempat di Ciater.

Untuk itu, penulis mengadopsi konsep yang ditawarkan oleh Soedarsono yang mengungkapkan ciri-ciri seni wisata yaitu, "(1) tiruan dari aslinya; (2) versi singkat atau padat; (3) dikesampingkan nilai-nilai sakral, magis, dan simbolis- 
nya atau nilai primernya; (4) penuh variasi;

(5) disajikan dengan menarik; dan murah harganya menurut ukuran kocek wisatawan." (Soedarsono, 2002: 273). Ciri-ciri yang disebutkan oleh Soedarsono tidak akan diadopsi keseluruhannya, namun akan dimodifikasi sesuai dengan ketentuan yang digariskan oleh salah satu prinsip dari World Tourism Organization (WTO) the Global Code of Ethics for Tourism (1999). Dalam artikel WTO ditulis bahwa "tourism activity should be planned in such a way as to allow traditional cultural products, crafts and folklore to survive and flourish, rather than causing them to degenerate and become standardized." Penulis tidak akan membuat standar tertentu dari produk-produk budaya tradisional yang dimiliki masyarakat Ciater, tetapi dalam konteks pembinaan masyarakat kami akan menjaga keasliannya serta menyesuaikan dengan interpretasi dan kreativitas masyarakat Ciater.

Jika kesenian tertentu memiliki nilai sakral dan simbolis, maka nilai-nilai itu akan tetap dipertahankan karena hal ini akan menjadi daya tarik tersendiri. Hal ini pun sesuai dengan Pasal 6 Undang-Undang No. 10 tahun 2009 yang menyatakan bahwa pelaksanaan rencana pembangunan kepariwisataan memper- hatikan keanekaragaman, keunikan, dan kekhasan budaya dan alam. Diharapkan kepariwisataan di Ciater dapat mencapai tujuan-tujuan yang dirumuskan di dalam Undang-undang, yaitu "meningkatkan pertumbuhan ekonomi, meningkatkan kesejahteraan, mengatasi pengangguran, melestarikan alam, lingkungan, dan sumber daya, memajukan kebudayaan, mengangkat citra bangsa, memupuk rasa cinta tanah air, memperkukuh jati diri dan kesatuan bangsa, dan mempererat persahabatan antarbangsa" (UU No. 10/2009).

\section{Model Pengembangan Desa Binaan}

Model Pengembangan Desa Binaan berbasis Wisata Seni dan Budaya ini dirancang untuk tujuan jangka panjang dalam kaitannya dengan peningkatan Indeks Pembangungan Manusia (IPM) yang meliputi indeks pendidikan, indeks kesehatan, dan indeks daya beli. Pengembangan ini memperhatikan keterpaduan pendidikan masyarakat dan keberlanjutan kegiatan yang digambarkan melalui program dan tahapan kegiatan seperti terlihat pada diagram 2. Rancangan ini semestinya dilaksanakan secara multitahun dengan peta jalan atau road-
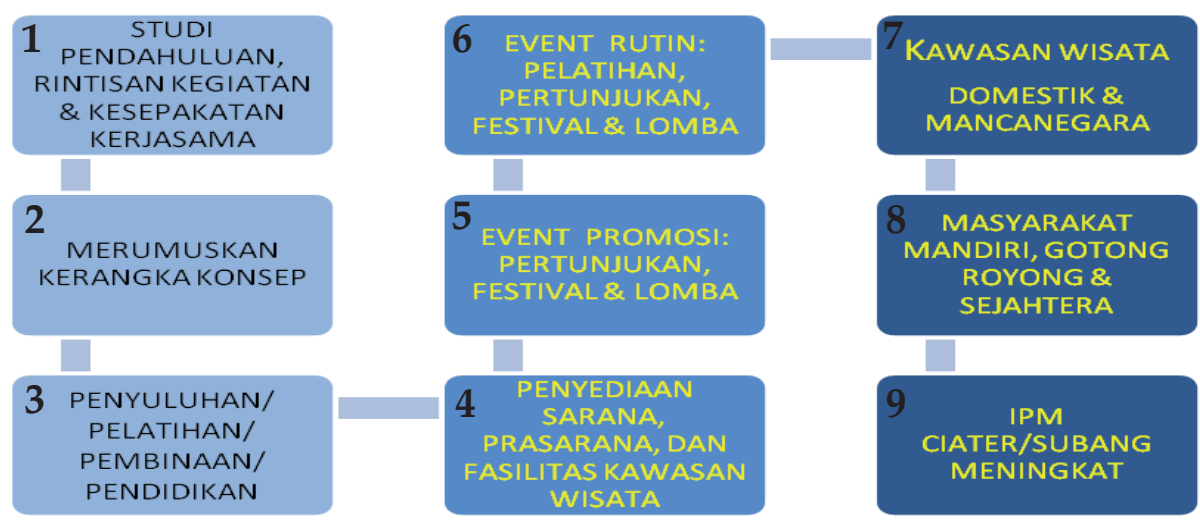

Diagram 2.

Rancangan Model Desa Binaan berbasis Wisata Seni dan Budaya map sebagai berikut: Tahun pertama adalah studi pendahuluan untuk memahami potensi, masalah, dan k e b u t u h an wilayah. Pe m a h a m an pembi- 
na diperlukan untuk mengetahui input yang akan dijadikan dasar perencanaan pengembangan program dan kegiatan.

Tahun kedua adalah merumuskan kerangka konsep dan implementasi program penyuluhan/pelatihan/pendidikan yang sasarannya adalah terwujudnya karya seni pertunjukan yang dapat ditonton wisatawan.

Tahun ketiga adalah penyuluhan/pelatihan/pendidikan dan penyediaan sarana dan prasarana untuk layanan wisata dengan tujuan terselenggaranya peristiwa wisata seni dan budaya. Penyediaan sarana dan prasarana ini dilakukan oleh pemerintah daerah setempat.

Tahun keempat adalah pemasaran acara-acara rutin kegiatan wisata yang marketable di kawasan wisata seni dan budaya yang dikelola langsung oleh masyarakat desa Ciater.

Tahun kelima adalah peristiwa rutin kegiatan wisata di kawasan wisata desa Ciater yang dikelola oleh masyarakat sehingga dampaknya adalah pendapatan meningkat untuk dapat mendorong peningkatan IPM Subang.

Pada tahun 2010-2011 telah dilaksanakan studi pendahuluan dan program rintisan untuk membangun kesepakatan kerjasama, merumuskan kerangka konsep, dan mengadakan pendidikan serta latihan (diklat) untuk mewujudkan model desa binaan berbasis wisata seni dan budaya. Adapun kegiatan praktis di lapangan dilakukan mulai dari studi pendahuluan dan kesepakatan kerjasama, proses pembinaan masyarakat melalui pendidikan dan pelatihan, dan mewujudkan wisata seni serta seni wisata.

\section{Studi Pendahuluan dan Kesepakatan Kerjasama}

Pada tahun 2010, Lembaga Penelitian dan Pengabdian Kepada Masyarakat UPI telah melaksanakan studi pendahuluan terhadap tiga wilayah yang akan dijadikan laboratorium sosial pendidikan (LABSOSDIK) LPPM UPI, yaitu Kota Bandung, Kabupaten Bandung, dan Kabupaten Subang. Dalam konteks pengembangan kawasan wisata, wilayah Ciater Kabupaten Subang menjadi pilihan LPPM. Pada awal diskusi dengan Camat Ciater di bulan Juni 2010, pembinaan desa diarahkan ke Desa Cisaat, karena desa tersebut merupakan $p i$ lot project Desa Peradaban yang mendapat bantuan dari Provinsi Jawa Barat.

Undang-Undang Kepariwisatan No. 9/2009 Pasal 12 ayat (1) tentang pengembangan kawasan wisata mesti memperhatikan kondisi strategis, antara lain: potensi pasar, lokasi strategis yang mempunyai peranan dalam usaha pelestarian dan pemanfaatan aset budaya, kesiapan dan dukungan masyarakat, dan kekhususan dari wilayah. Setelah penulis mengobservasi lokasi dan keadaan masyarakat Desa Cisaat, ternyata desa tersebut kurang tepat untuk dijadikan kawasan pengembangan wisata seni dan budaya. Lokasinya agak sulit dijangkau dengan kendaraan umum, potensi pasar belum ada, dan masyarakatnya kelihatan belum siap untuk dijadikan tujuan wisata seni dan budaya.

Di sisi lain, pasar sudah ada di Desa Ciater karena desa ini sudah menjadi daerah tujuan wisata dengan daya tarik kolam pemandian air panas Sari ater. Daya tarik lainnya adalah pegunungan dan hamparan hijau kebun teh. Desa Ciater 
ini sangat mudah dilalui oleh kendaraan umum maupun pribadi, karena letaknya di sepanjang jalan raya utama yang menghubungkan kota Bandung dengan Subang dan menembus ke arah Jakarta. Selain ini, Kepala Desa Ciater dan masyarakatnya memiliki perhatian terhadap kesenian. Kegiatan kesenian sudah ada di Ciater, baik di masyarakat maupun di sekolahsekolah. Namun kesenian tersebut belum dijadikan daya tarik pariwisata. Dari sisi lokasi, situasi alam, dan keadaan masyarakatnya, Desa Ciater sangat tepat untuk dijadikan permodelan Desa Binaan berbasis Wisata Seni dan Budaya.

Program rintisan yang peneliti laksanakan pada bulan Juli-Agustus 2010 adalah tentang penggalian dan modifikasi permainan anak-anak sebagai suatu pertunjukan seni. Dengan harapan, para guru di Sekolah Dasar dapat mengembangkan bahan ajar untuk mata pelajaran seni budaya di jenjang Sekolah Dasar. Hasil kegiatan ini berupa seni pertunjukan berbasis potensi lokal kaulinan barudak yang ditampilkan pada acara perpisahan KKN se-Kabupaten Subang yang bertempat di Kampung Dawuan, Desa Ciater pada tanggal 28 Agustus 2010. Pada saat itu, Kampung Dawuan ditetapkan sebagai 'Kawasan Pengembangan Desa Wisata Alam, Seni, dan Budaya' oleh Kepala Desa Ciater. Pada saat itu pula, Kepala Desa Ciater telah menandatangani kesepakatan kerjasama dengan Kepala Pusat Studi Wanita, Seni, dan Budaya, Lembaga Penelitian dan Pengabdian Kepada Masyarakat, Universitas Pendidikan Indonesia (PSWSB LPPM UPI) yang diketahui oleh Bupati Subang dan Ketua/Sekretaris LPPM UPI. Dengan kata lain, program rintisan pengabdian kepada masyarakat dilakukan sebagai bagian dari pendekatan struktural dan sosial kepada masyarakat untuk selanjutnya diikat dalam bentuk kesepakatan kerjasama.

Selanjutnya, penulis mengadakan studi tentang pertunjukan seni tradisional untuk pariwisata di Ciater. Seni tradisional dipentaskan hanya memenuhi pesanan atau dalam rangka hajatan di masyarakat. Salah seorang warga Desa Ciater menuturkan bahwa 'sewaktu ada hajatan di masyarakat, wisatawan asing sengaja mengunjunginya dan mereka senang menonton kesenian yang ditampilkan.' Di Sari ater, kesenian tradisional tidak rutin dipentaskan. Dalam leaflet, Sari ater menawarkan paket hiburan calung seharga Rp. 2.000.000, Sisingaan seharga Rp. 3.500.000, dan Jaipongan seharga Rp. 4.500.000. Menurut Soedarsono (2002) tontonan kesenian untuk pariwisata diperlukan harga murah menurut kocek wisatawan dan penuh variasi. Harga jual yang ditawarkan oleh Sari ater relatif mahal dan hanya dapat dibeli oleh wisatawan dalam sebuah rombongan, sedangkan wisatawan yang datang secara individual tidak mungkin mau membeli dengan harga tersebut. Sajiannya pun cenderung hanya satu jenis tontonan.

Hal ini berbeda dengan di Saung Angklung Udjo, dengan uang Rp. 50.000 (limapuluh ribu rupiah) wisatawan dapat menonton Wayang Golek, musik angklung, Arumba, tari Jaipongan, dan tari Topeng. S.A.U telah berkembang menjadi satu-satunya kawasan wisata seni Sunda di kota Bandung yang berhasil memanfaatkan angklung sebagai daya tarik pariwisata. Dengan angklung, Udjo dapat mengangkat nama Jawa Barat dan Indonesia. Masyarakat di sekitarnya dapat hidup dengan keterlibatan sebagai pemain, pengrajin, pegawai, pedagang, dan pengelola. 
Kepala Desa dan masyarakat Ciater berkeinginan untuk membangun pusat kegiatan seni seperti yang dikembangkan di S.A.U. Wisatawan nusantara dan mancanegara sebagai pengguna sudah jelas ada dan rutin. Beberapa kegiatan yang pernah dilaksanakan seperti festival/lomba Kaulinan Barudak antar SD, pertunjukan seni tradisional Celempung dan Jaipongan, Ulang Tahun Kecamatan, belum dapat menarik wisatawan. Permasalahannya adalah, bagaimana mengembangkan seni tradisional setempat untuk tontonan wisatawan? Di Ciater belum ada pusat atau organisasi kesenian yang mengkhususkan pada garapan seni untuk wisata. Tari Jaipongan, Celempungan, dan Sisingaan, serta seni lainnya masih disajikan sebagaimana pertunjukan aslinya dalam rangka hajatan untuk penonton orang Subang.

\section{Proses Pembinaan Masyarakat}

Pada tahun 2011, setelah kerangka konsep pengembangan desa binaan berhasil dirumuskan seperti di atas, maka tim dosen UPI merancang proses pembinaan masyarakat melalui pendidikan dan pelatihan (diklat) serta pertunjukan untuk tiga kelompok sasaran, yakni pengrajin angklung, pelatih angklung, dan pemain angklung. Sasaran masyarakat pada setiap kelompok disesuaikan dengan minat dan latar belakangnya. Pendidik/pelatih/tutor angklung adalah guru-guru SD dan SMP di kecamatan Ciater. Pemain angklung adalah siswa sekolah dari SD yang ada di Desa Ciater atau anak yang tidak bersekolah. Pengrajin angklung berasal dari masyarakat desa Ciater yang belum memiliki pekerjaan tetap, khususnya di Kampung

\section{Dawuan.}

Sebelum dilaksanakan kegiatan pembinaan, tim dosen dari LPPM melakukan advokasi kepada Dinas Kebudayaan, Pariwisata, Pemuda dan Olah Raga (Disbudparpora) Subang. Selanjutnya, rangkaian kegiatan diklat, pelatihan membuat angklung, memainkan angklung, serta mewujudkan pertunjukan sebagai bagian dari wisata seni dan budaya. Praktik pelaksanaan diklat dan pertunjukan melibatkan semua unsur masyarakat yaitu guru, siswa, seniman, keluarga, pamong desa, tokoh masyarakat, pejabat kecamatan dan UPTD Kecamatan Ciater, pemilik restoran dan perusahaan perkebunan teh, dosen lintas jurusan seni FPBS UPI, S.AU., mahasiswa KKN UPI, dan para kepala pusat di lingkungan LPPM UPI. Waktu kegiatan dilaksanakan pada bulan Mei sampai Oktober 2011.

\section{Advokasi}

Pada tanggal 27 Mei 2011, Tim LPPM UPI dan Saung Angklung Udjo mengadakan advokasi ke Dinas Pariwisata, Kebudayaan, Pemuda dan Olah Raga (Disparbudpora) Subang yang dihadiri oleh BAPPEDA Subang, Dinas Pendidikan, Camat dan Kepala Desa Ciater. Kegiatan ini dilaksanakan sebelum rangkaian proses pembinaan masyarakat di Ciater. Advokasi ini merupakan upaya untuk memperoleh dukungan dari para pejabat pemerintah Kabupaten Subang tentang rencana pengembangan desa binaan berbasis seni dan budaya.

Penulis mempresentasikan rancangan kegiatan dan target-target luaran dari program yang akan dilaksanakan, sedangkan Sam Udjo dari S.A.U memaparkan 
pengalaman ayahnya, Udjo Ngalagena. Sam Udjo memaparkan berbagai usaha ayahnya untuk membangun pariwisata angklung. Pada kesempatan ini juga, tim pemain angklung yaitu mahasiswa UPI mempertunjukan permainan angklung Sunda sebagai sampel materi yang akan dilatihkan di Ciater. Sambutan mereka cukup bagus, bahkan Kepala Disbudparpora menjanjikan untuk membeli seperangkat angklung Sunda, meskipun sampai akhir kegiatan 2011 tidak dibelikan.

Sebelum pendidikan dan pelatihan dimulai, pada tanggal 12 Juli, penulis sebagai ketua tim pengabdian kepada masyarakat dan dosen pembimbing KKN mengadakan pertemuan dengan Camat Ciater, yang diwakili oleh Kepala Bidang Sosial dan tujuh kepala desa se-Kecamatan Ciater untuk menyerahkan 63 mahasiswa KKN UPI tema POSDAYA serta menyampaikan rencana program Pengabdian kepada Masyarakat yang akan dilaksanakan oleh Tim Dosen UPI.

\section{Pendidikan dan Pelatihan}

Pendidikan dan pelatihan bagi para pendidik bertujuan untuk menyiapkan pelatih angklung yang sekaligus pendidik seni yang mampu mengembangkan angklung Sunda sebagai medium apresiasi dan kreativitas dalam pembelajaran seni budaya terutama di SD terkait dengan musik daerah setempat (Sunda). Kelompok guru yang dilatih angklung adalah kelompok guru yang pada tahun 2010 telah mendapat pelatihan mengkemas kaulinan barudak sebagai suatu seni pertunjukan. Kelompok guru ini dilatih untuk dapat bermain angklung dan cara mengajarkan angklung kepada anak-anak. Selanjutnya, dipilih SD untuk dijadikan pusat latihan angklung. Guru yang terlibat ditentukan kemudian. Guru lain yang tidak menjadi pelatih angklung akan diarahkan untuk berkreasi kaulinan barudak di masing-masing sekolah tempat mereka mengajar.

Pada tanggal 18-20 Juli 2011, diklat guru dan kepala sekolah dilaksanakan yang bertempat di Kantor Kecamatan Ciater. Pada tanggal 18-19 Juli 2011, diklat dilaksanakan dengan melibatkan 40 orang guru dan kepala sekolah. Tujuan diklat ini adalah untuk meningkatkan kesadaran dan wawasan guru serta kepala sekolah tentang pentingnya pendidikan, seni dan budaya, serta pemeliharaan lingkungan dalam konteks pariwisata di Ciater. Materi utama dalam diklat adalah angklung Sunda. Namun demikian, dalam praktiknya dimasukkan materi lainnya seperti inovasi pendidikan, manajmen berbasis sekolah dan tuntas wajar Dikdas, teknologi pengolahan sampah organik dan an-organik. Materi tambahan tersebut diharapkan dapat membantu guru meningkatkan pemahaman tentang pentingnya pendidikan dan kebersihaan lingkungan untuk keberlanjutan kehidupan. Instruktur pada kegiatan ini dibantu oleh Para Kepala Pusat LPPM UPI, dan Sam Udjo dari Yayasan Saung Angklung Udjo. Pada tanggal 20 Juli 2011, kegiatan diklat dilanjutkan dengan merumuskan skenario garapan seni wisata. Dalam kegiatan itu, para seniman setempat diajak berdiskusi untuk mengidentifikasi seni-seni yang ada di Ciater dan menyusun urutan sajiannya. Hasil identifikasi ini adalah jenis kesenian yang ada di Ciater dengan urutan dari mulai celempungan, kreasi kaulinan barudak dan Angklung, gembyungan, calung, Jaipongan, dan singa depok. 


\section{Latihan Memainkan Angklung}

Latihan memainkan angklung dilaksanakan bersamaan dengan pelatihan tutor Angklung yang dijadwalkan pada tanggal 21 s.d. 29 Juli 2011. Tujuannya adalah melatih para guru seni budaya untuk menjadi tutor angklung Sunda dengan belajar langsung pada saat siswa SD berlatih memainkan angklung. Pelatihan tutor dalam jumlah banyak ternyata tidak efektif. Oleh karena itu dipilih tiga guru seni budaya dari dua SD di Desa Ciater untuk turut bergabung bersama tim dosen UPI melatih para siswa bermain angklung dan menari kaulinan barudak.

Pada tanggal 1 s.d. 16 Agustus 2011 latihan angklung berlangsung di tengah bulan puasa. Lapar dan dahaga tidak mengurangi semangat 60 siswa Sekolah Dasar Ciater dan Giri Aji serta lima pelatih untuk bermain angklung. Seniman setempat membantu menabuh kendang, gong, dan calung. Sam Udjo menjadi instruktur angklung Sunda, sedangkan penulis menjadi instruktur tari. Materi yang dilatihkan adalah lagu anak-anak dan lagu pengiring (oray-orayan, kacang buncis, boboyongan, gonjing, kembang tanjung, dan es lilin), permainan anak-anak atau kaulinan $b a$ rudak, tari, sisingaan anak, dan Jaipongan. Produk akhir dari latihan ini adalah sebuah pertunjukan kesenian yang diawali oleh permainan anak dengan lagu jaleuleuja, perepet jengkol, boboyongan, oray-orayan, kacang buncis, singingaan anak-anak, dan diakhiri dengan tari Jaipongan.

Di sela-sela latihan, Bapak kepala Desa Ciater, tim dosen UPI, dan Sam Udjo menggagas untuk mendirikan 'Sanggar Seni Ciater Pasti Panineungan' pada tanggal 29 Juli 2011. Tujuan pendirian sanggar seni ini adalah untuk upaya keberlanjutan kegiatan kesenian. Struktur keorganisasian terdiri dari pamong desa, guru SD, tokoh masyarakat, TIM UPI, dan S.A.U. Tim UPI dan S.A.U akan berperan sebagai mitra.

\section{Pelatihan Pembuatan Alat Musik Ang- klung}

Latihan membuat alat musik angklung dilaksanakan pada tanggal 21 Juli s.d. 16 Agustus 2011di Kampung Dawuan Desa Ciater. Kampung Dawuan terdiri dari dua RT dari Desa Ciater yang pekerjaan masyarakatnya cenderung homogen, yaitu sebagai pemetik teh. Lokasi kampung ini agak jauh terpisah dari pusat pemerintahan Desa Ciater. Dari satu sisi Kepala Desa menghendaki tempat latihan pembuatan angklung di Balai Desa, di sisi lain masyarakat kampung Dawuan menginginkan di Kampung Dawuan saja. Instruktur kegiatan adalah Handiman dari Saung Angklung Udjo dan Bandi Subandi, dosen seni rupa UPI. Tim pelatih menyetujui untuk latihan di Kampung Dawuan, namun demikian kegiatan latihan hanya terlaksana empat kali di tempat tersebut.

Pelatihan membuat angklung bagi pengrajin dilaksanakan bersamaan dengan pelatihan guru. Sasaran pesertanya adalah masyarakat kampung Dawuan yang memiliki minat besar, ketekunan dan pendengaran yang baik terhadap bunyi. Pelatihan meliputi pengenalan karakteristik bambu, teknik meraut, teknik membuat rangka angklung, teknik membuat lubang (cowakan) angklung, dan teknik melaras.

Semula, peserta yang mengikuti latihan adalah perempuan semua sebanyak 10 orang. Namun pada latihan kedua diikuti oleh peserta laki-laki enam orang dan peserta perempuan hanya satu orang 
saja. Pada hari ketiga latihan, pesertanya hanya tinggal tiga orang. Dari tiga kali latihan, mereka baru bisa membuat rangka angklung, sedangkan untuk membuat tabung dan menyetel suara belum bisa. Jenis bambu di hutan dekat kampung Dawuan sangat memungkinkan untuk dapat dibuat angklung. Namun demikian, dari mulai penebangan sampai siap dibuat angklung diperlukan waktu enam bulan. Dari 7 orang peserta pelatihan membuat angklung, yang berlanjut ingin menekuni sebagai pengrajin alat musik angklung hanya tinggal dua orang saja. Selanjutnya, kedua orang tersebut dilatih di Saung Angklung Udjo sebagai pengrajin. Pelatihan membuat alat musik angklung dilanjutkan di kecamatan Ciater dengan peserta yang lebih banyak, yaitu perwakilan dari desadesa se-kecamatan Ciater. Sebenarnya hasil latihan ini mempunyai nilai ekonomi secara langsung yang dapat meningkatkan pendapatan mereka. Saung Angklung Udjo langsung dapat membeli hasil latihan dan produk rangka angklung dari para pengrajin. Beberapa pengrajin sangkar burung dan bilik rumah di Ciater menambah kegiatan sehari-harinya membuat rangka dan tabung angklung untuk menambah pendapatannya.

\section{Wisata Seni dan Seni Wisata}

Wisata seni adalah peristiwa wisata dimana seni menjadi tujuan kunjungan wisatawan, sedangkan seni wisata adalah sajian seni yang memperhatikan waktu yang singkat, materi seni yang bervariasi, disajikan secara menarik, murah harganya, dan unsur simbolis atau sakralnya dihilangkan. Dalam konteks wisata seni ini salah satu sajiannya adalah seni wisata, sebuah kreativitas seni yang bertujuan untuk dijual kepada wisatawan. Untuk mewujudkan wisata seni dan seni wisata, kegiatan pengkemasan jenis-jenis permainan anakanak dan kesenian lokal dilakukan dua putaran atau siklus.

Siklus pertama dilakukan melalui proses pelatihan angklung dengan menggabungkan permainan anak-anak, tari, Sisingaan kecil, dan seni tradisi daerah setempat. Cara dan materi tersebut adalah untuk memberi solusi atas permasalahan keterpisahan jenis-jenis kesenian yang ada di Ciater. Namun demikian, seni daerah setempat pada siklus pertama tidak dilibatkan karena faktor biaya produksi yang minim, sehingga tim pembina hanya memfokuskan pada garapan jenis-jenis kesenian yang bisa ditampilkan oleh anak-anak sekolah. Melalui proses latihan angklung tanggal 1 s.d. 16 Agustus seperti dipaparkan di atas, pada tanggal 17 Agustus 2011 bertepatan dengan Hari Kemerdekaan Republik Indonesia, hasil latihan memainkan angklung dipertunjukan di Pekarangan Kecamatan Ciater. Tim dosen UPI, S.A.U., guru SD, siswa SD Giri Aji dan SD Ciater, tiga orang seniman, pamong desa Ciater, pihak kecamatan $\mathrm{Ci}$ ater ini berhasil mewujudkan karya seni yang dapat ditonton oleh masyarakat. Mahasiswa KKN UPI membantu pelaksanaan kegiatan secara keseluruhan.

Pertunjukan disajikan selama 20 menit dengan susunan dimulai dari kreasi kaulinan barudak, angklung Sunda, Sisingaan anak-anak, dan tari Jaipongan. Seorang anak laki-laki menyerukan "jaleuleu...!" sambil berlari-lari yang kemudian dijawab oleh sembilan anak laki-laki lainnya dengan "ja...!". Setelah sepuluh anak laki-laki tersebut berkumpul, kemudian mereka menari dan berkelakar serta meng- 
ajak bermain boboyongan. Lagu boboyongan dimainkan oleh sekelompok anak lakilaki dan perempuan dengan angklung sambil masuk ke arena pentas. Pada saat itu, sepuluh anak perempuan bermain ucing-ucingan sambil berlari-lari diikuti oleh anak laki-laki yang telah masuk lebih dulu. Suasana pada adegan ini menjadi riuh, namun setelah pemain angklung menempatkan diri berjajar suasana menjadi sepi yang terdengar adalah sekelompok anak perempuan menyanyikan lagu ompimpah dalam bentuk lingkaran. Ketika anak perempuan ini membentuk barisan panjang seperti ular dan mempersiapkan diri menyanyikan lagu oray-orayan, dua kelompok anak laki-laki membuat gerak perepet jengkol sambil bertepuk tangan dan menjatuhkan diri. Saat itu, barisan 20 anak perempuan yang membentuk ular bernyanyi oray-orayan dan menari menuju arena pentas diiringi angklung Sunda. Sekelompok anak perempuann juga menari diiring lagu kacang buncis. Pada akhir sajian tari, dua kelompok anak laki-laki menandu singa kecil diiringi lagu gonjing dengan tempo yang cepat masuk ke arena pentas. Mereka mendemontrasikan permainan dua singa yang masing-masing ditandu oleh empat orang anak laki-laki. Setelah itu, kelompok sisingaan kecil menutup rangkaian acara dengan mengelilingi arena pentas diikuti oleh rombongan penari dan pemain angklung. Setelah pertunjukan kaulinan barudak selesai ditampilkan, delapan anak perempuan menari Jaipongan diiringi musik angklung Sunda dengan lagu Kembang tanjung dan Es lilin. Para pemain dan penonton yang kebanyakan orang tua siswa dan pejabat pemerintah se-kecamatan Ciater cukup puas menyaksikan pertunjukan tersebut.

Meskipun masyarakat Ciater sudah berhasil mempertunjukan kesenian yang disajikan oleh anak-anak SD, namun wisata seni belum berhasil karena penontonnya adalah masyarakat sekitar Ciater bukan wisatawan. Oleh karena itu, penulis merencanakan siklus kedua untuk melibatkan wisatawan, baik mancanegara maupun nusantara sebagai penontonnya.

Pada siklus kedua, kami melakukan proses pembinaan kembali kepada siswa $\mathrm{SD}$, dan guru SD, seniman setempat dengan menambah materi kesenian dan personalnya dari rombongan celempungan dan singa depok dewasa. Seniman daerah setempat dilibatkan lebih banyak, karena dana untuk transport mereka akan diperoleh dari calon penonton. Penontonnya adalah wisatawan nusantara dan mancanegara yang dikaitkan dengan acara sight seeing peserta Festival dan Workshop Musik Kontemporer Komponis Muda Asia Tenggara. Kegiatan internasional workshop dan festival komponis muda Asia Tenggara merupakan kerjasama Universitas Pendidikan Indonesia dan Goethe Institut (sebuah Yayasan Jerman yang memfokuskan pada budaya) yang dilaksanakan di Bandung dari tanggal 28 September sampai dengan 9 Oktober 2011. Pada saat persiapan acara festival tersebut, panitia dari Goethe Institut merencanakan acara sight seeing untuk

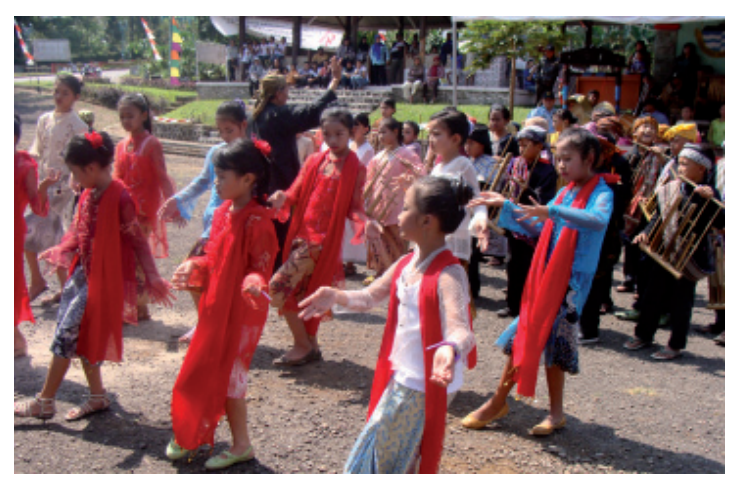

Foto 1

Pertunjukan Tari \& Angklung tanggal 17 Agustus 2011 (dok. Juju M, 2011) 
50 peserta, juri, dan tamu dari Jerman dan Asia Tenggara pada hari Jumat, 7 Oktober 2011. Penulis sebagai ketua pelaksana kegiatan fesival ini menawarkan untuk menonton seni tradisional di Desa Ciater dan mendaki gunung Tangkuban Perahu, dan tawaran ini disetujui.

Pada hari Minggu, 11 September 2011 Artistik Direktur festival komponis muda dari Jerman, Dieter Mack, berdiskusi dengan Kepala Desa dan Camat Ciater untuk acara wisata. Kedua tokoh masyarakat Ciater ini hampir tidak percaya dikunjungi oleh 'orang bule' untuk tujuan wisata seni di Ciater. Namun demikian, mereka gembira dan menyatakan siap untuk menerima tamu dengan suguhan kesenian. Pada saat itu, penulis dan kepala desa mengidentifikasi materi kesenian yang akan ditampilkan antara lain angklung dan kaulinan barudak yang pernah ditampilkan pada acara 17 Agustus 2011, lagu pop Sunda, celempungan, serta sisingaan anak dan si$n g a$ depok oleh orang dewasa. Pertunjukan seni disajikan secara singkat selama 1 jam, penuh variasi, menarik, dan murah harganya.

Kepala Desa dan Camat Ciater mendiskusikan lokasi tempat pertunjukannya, karena menurut penulis pekarangan kecamatan Ciater kurang menarik untuk setting pertunjukan seni. Pada tanggal 30 September 2011, kepala Desa Ciater menginformasikan bahwa tempat pertunjukan akan dilaksanakan di lingkungan 'Saung Walini' yaitu restoran baru yang mempromosikan nasi liwet. Tempat ini berada di sekitar perkebunan teh PTPN VIII dengan latar belakang gunung, rumah adat, sekelilingnya terdapat saung-saung tempat makan. Ketika penulis mengobservasi tempat ini dan menemui pemiliknya, ternyata pemilik restoran 'Saung Walini' sudah mengi- zinkan tempatnya untuk dijadikan arena pertunjukan.

Pada tanggal 2 Oktober 2011 seniman singa depok diundang oleh Kepala Desa untuk bergabung berlatih bersama anak-anak dan mengenal lokasi pertunjukan. Sam Udjo dan penulis juga hadir pada saat itu. Sam Udjo memilih rumah adat dan perkebunan sebagai setting pentas, sedangkan pekarangan restoran sebagai arena pentas. Kepala Desa menyusun acara sajian yang diawali dari sajian musik celempungan untuk menyambut tamu, ucapan selamat datang dari pembawa acara, lagu pembuka Ciater panineungan, musik celempungan, angklung dan kaulinan barudak, singa depok anak, singa depok dewasa, tari Jaipongan, dan bermain angklung bersama wisatawan. Biaya paket wisata ini sebesar Rp. 5 juta rupiah untuk 50 orang wisatawan, yang dikelola langsung oleh Kepala Desa dan pengurus sanggar seni Desa Ciater.

Peristiwa wisata seni angklung Sunda terjadi pada tanggal 7 Oktober 2011 di desa Ciater, Subang. Hari Jumat, 7 Oktober 2011, jam 8 pagi 70 orang wisatawan yang terdiri dari 50 orang wisatawan mancanegara dan 20 orang wisatawan nusantara dari berbagai daerah di Indonesia berkunjung ke Ciater untuk menyaksikan pertunjukan kesenian. Pukul 07.00 wib., sekitar 70 siswa SD, 10 orang seniman celempungan, dan 20 orang seniman sisingaan bersiapsiap dengan kostum pertunjukan. Pamong Desa, guru SD, orang tua siswa, pedagang kerajinan sisingaan mini, pedagang es, tukang parkir, dan sekitar 100 siswa SD hadir sebagai penonton. Setibanya, wisatawan di 'Saung Walini', musik celempungan dibunyikan menyambut kedatangan mereka, tiga seniman setempat berpakaian kampret hitam menari sambil mempersilakan tamu untuk duduk. Dua orang wi- 


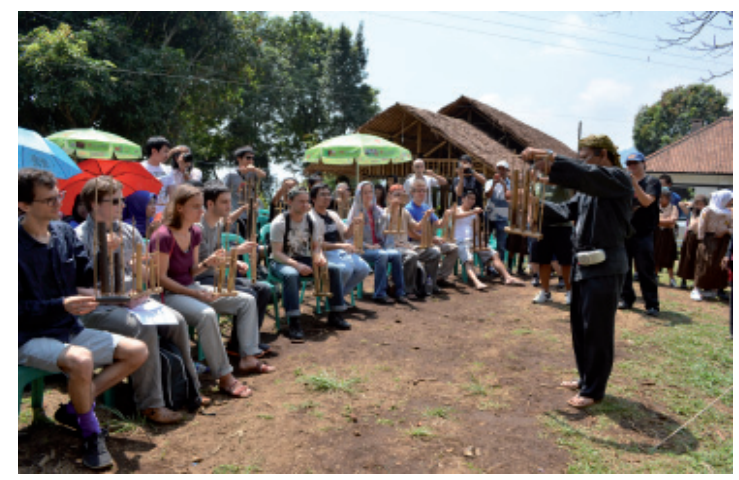

Foto 2

Wisatawan bermain Angklung Sunda (Cici, 2011)

satawan mancanegara secara spontan bergabung menari bersama penyambut tamu, tamu lainnya memperhatikan jenis musik celempungan ini. Penulis sendiri berperan sebagai pembawa acara mempersilahkan tamu untuk duduk seraya mengucapkan selamat datang. Acara selanjutnya adalah lagu 'Ciater Panineungan' dinyanyikan oleh Alek Hidayat, Kepala Desa Ciater yang sekaligus pencipta lagu tersebut. Susunan acara selanjutnya adalah celempungan, angklung dan kaulinan barudak, sisingaan anak, singa depok dewasa, tari Jaipongan, dan diakhiri dengan bermain angklung Sunda bersama wisatawan. Selain menyaksikan pertunjukan, wisatawan dilibatkan untuk menaiki sisingaan dan bermain angklung. Pada akhir kegiatan, salah seorang guru yang bertanggungjawab konsumsi membagikan makanan tradisional (kacang tanah, ubi, singkong, dan pisang molen) yang dibungkus plastik disajikan dengan air minum.

Salah seorang dosen dari University of Philippines, Dr. Jonas Baes mengatakan kepada penulis bahwa dia terinspirasi untuk mengadakan kegiatan serupa di Filipina. Semua penonton mengucapkan terimakasih kepada masyarakat Ciater. Secara khusus, pemain biola grup ensemble mo-

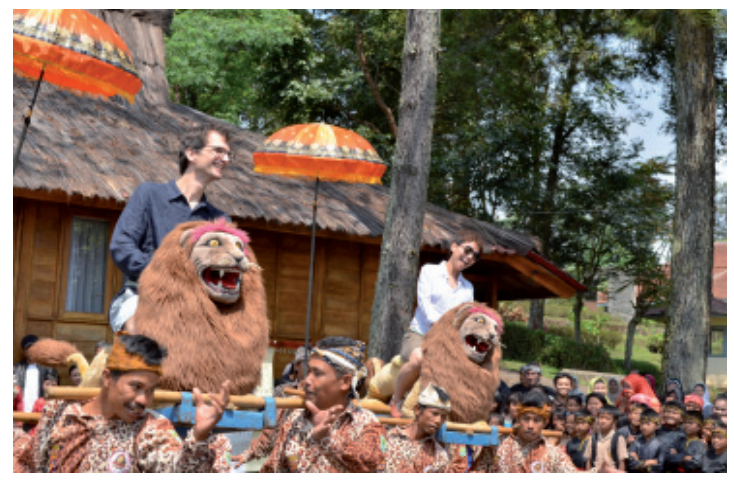

Foto 3

Wisatawan menunggang Sisingaan (Cici, 2011)

saik dari Jerman, Karen Lorenz menulis "I loved to play Angklung and the girls were so cute." Dirigen Robert Platz yang pertama kali berkunjung ke Indonesia menyatakan "very impressive to see and hear. I was thankful for the opportunity to learn about Angklung". Martin Losert menulis "a new kind of music with interesting instruments. We see a litle bit of the area around of Bandung".

Kepala Desa Ciater dan semua seniman yang terlibat serta siswa SD sangat gembira mementaskan hasil karyanya dan mendapat apresiasi dari orang luar negeri. Mereka berencana untuk melanjutkan latihan kesenian tersebut. Bahkan, Kepala Desa Ciater berencana untuk memohon bantuan pemerintah Subang membangun sanggar seni di Kampung Dawuan untuk kegiatan latihan dan berkesenian, karena selama ini latihan kesenian dilaksanakan di Balai Desa Ciater. Penulis berpandangan bahwa kegiatan ini cukup berhasil sebagai upaya mewujudkan wisata seni pada siklus kedua ini. Masyarakat Ciater maupun wisatawan mendapat pengalaman yang berharga. Namun demikian, kegiatan ini perlu dilanjutkan dan dikelola secara profesional agar menjadi budaya masyarakatnya dan meningkatkan pendapatan mereka. 


\section{Penutup}

Mewujudkan model desa binaan berbasis wisata seni dan budaya yang memanfaatkan musik angklung Sunda dan seni tradisional daerah setempat di Ciater dilaksanakan melalui kerjasama tiga pihak yaitu akademisi (tim dosen UPI), praktisi (semua unsur masyarakat desa), dan industri (Yayasan Saung Angklung Udjo). Ketiganya berperan aktif dalam proses perencanaan dan pelaksanaan: pendidikan, pelatihan, pertunjukan, dan promosi wisata seni. Semua unsur masyarakat Ciater yaitu guru, siswa, seniman, keluarga, pamong desa, dan akademisi berperan aktif untuk meningkatkan inovasi dan kreativitasnya dalam jasa layanan wisata seni yang diwujudkan pada tanggal 7 Oktober 2011 di Ciater. Pertunjukan seni wisata ini memperhatikan ciri-ciri seni wisata yang ditawarkan oleh Soedarsono (2002).

Apabila proses latihan dan pertunjukan dilaksanakan secara rutin, maka jasa wisata seni di Ciater ini akan mempunyai nilai ekonomi yang akan meningkatkan kesejahteraan masyarakatnya. Dengan membuat suatu pertunjukan, banyak pihak yang terlibat antara lain pedagang, tukang parkir, restoran, petugas kebersihan, dan penonton yang datang dari masyarakat setempat. Melalui kegiatan ini, nilai gotong royong dan toleransi yang mengarah pada pembentukan karakter bangsa akan terbangun. Sikap apresiasi masyarakat terhadap seni tradisional akan meningkat karena termotivasi oleh wisatawan asing yang juga mau belajar seni tradisional daerahnya. Disinilah budaya pariwisata dan pariwisata budaya sebagaimana yang diungkapkan oleh Picard (2006) dapat diwujudkan di Ciater, Kabupaten Subang, dengan bantuan akademisi yang memiliki komitmen dan pihak industri wisata yang berpengalaman.

\section{DAFTAR PUSTAKA}

Juju Masunah dan A. Sunaryo

2010 Pengembangan Desa Sehat dan Sejahtera sebagai Laboratorium Sosial \& Pendidikan di Kabupaten Subang. Laporan PPM, UPI Bandung.

Juju Masunah, et al.

2003 Angklung di Jawa Barat: Sebuah Perbandingan. Bandung: P4ST UPI.

Picard, Michel

2006 Bali: Pariwisata Budaya dan Budaya Pariwisata. Jakarta: KPG (Kepustakaan Populer Gramedia).

R.M. Soedarsono

2002 Seni Pertunjukan Indonesia di Era Globalisasi. Jogjakarta: Gadjah Mada University Press.

T. Narawati

2009 Seni Wisata: Kemasan Industri Kreatif di Jawa Barat. Laporan Penelitian, UPI Bandung.

\section{Sumber lain:}

1. Undang-undang Nomor 10 Tahun 2009 tentang Kepariwisataan (Lembaran Negara Republik Indonesia Tahun 2009 Nomor 11, Tambahan Lembaran Negara Republik Indonesia Nomor 4966).

2. World Tourism Organization Global Code of Conduct of Tourism.1999. 